\title{
Qualifications must address the needs of commerce in Zimbabwe: A case of the Hospitality Discipline
}

\author{
Woyo Erisher \\ Head of Division On Job Education and Training Management Harare Polytechnic P. O. Box CY 407, \\ Causeway, Harare, Zimbabwe
}

\begin{abstract}
This paper documents a multi-perspective evaluation into the training needs of the hospitality and tourism industry in Zimbabwe. Research on training needs is important, especially in the hospitality industry, which is known for its traditional approach in terms of human resource management. This paper aims to develop an understanding of the current situation concerning hospitality graduates' as well as hospitality managers' skillsand competencies and career development. The key purpose is seen to be the preparation of graduates that meets the needs of industry and commerce.
\end{abstract}

Key words: Qualifications, Hospitality discipline, competencies

\section{Introduction}

The thrust of this paper was to compose a discussion on the state of Hospitality training in Zimbabwe and its ability to meet the needs of industry and commerce. This study also sought to unearth the weakness of the current Hospitality training in Zimbabwe and what needs to be done in an attempt to produce competent hospitality professionals as envisaged by the industry. This paper gives a critique on the current curriculum being offered by Polytechnics and Universities in Zimbabwe with regards to Hospitality training.

It is now a known fact that Hospitality and Tourism is the driver of economic competitiveness yet there is little or no visible sign of the development of post graduate Tourism and Hospitality qualifications locally (STERP, 2009). UNWTO (2012) claims that a record one billion tourists crossed international boundaries, while between 5 to 6 billion tourists have travelled within their countries. In 2012, tourism generated $9 \%$ of global Gross Domestic Product (GDP); 1 in every 12 jobs was tourism related; and it also generated about US $\$ 1.2$ trillion which signifies $6 \%$ of world trade (WTO, 2012). Travel and tourism industries generate employment for approximately 250 million people or one in every eleven jobs (World Travel and Tourism Council, 2002). In Zimbabwe, employment in tourism is currently 300000 persons (ZTA Statistics, 2012) yet there is a lack of appropriately skilled human resources. Thus, it becomes imperative for this paper to find out if this lack of appropriately skilled human resources has something to do with the curriculum of the hospitality professionals.

Whilst it is appreciated that hospitality training in Zimbabwe is a young profession, theoretically, it was the oldest to be practiced, but the recognition of the function was slow due to the lack of developmental programmes in the profession. Local universities have worsened the situation by their slow speed to adapt to the changing needs of industry and commerce. Recognition of Tourism and Hospitality as a key driver in the Zimbabwean economy will require that tertiary institutions expedite the process of developing relevant Hospitality graduates that will make a difference in industry (STERP, 2009). The plea of this paper is that awareness of Hospitality is raised and that the local qualifications being offered must address the needs of industry and commerce expected of hoteliers. Higher Education Institutions (HEIs) must start seriously to develop a curriculum that meets the needs of the Tourism and Hospitality Industry in Zimbabwe and the rest of the world. There is need for a qualification that is industry driven and universal, standard and recognised around the world.

Scholars such as Airey and Johnson (1999) argued that the tourism and hospitality tertiary education courses must aim to meet demands of a volatile and changing world. Thus, it becomes imperative for this paper to explore and find out the state of affairs in terms of hospitality training in Zimbabwe. Tourism and hospitality employers have concerns regarding the scarcity ofsuitably qualified, competent staff, particularly staff with managerial potential (Cooper et al, 1992). The colleges and universities in Zimbabwe deliver degrees and diplomas and these courses involve at least three years of on-campus study covering a range of disciplines aimed at preparing students for management careers in tourism and hospitality. Additionally, students are required to take a 12 month compulsory internship inan industrial setting as a partial fulfilment of the requirements of their degree or diploma qualifications.

Most tourism courses are designed to develop managers of the future. This means the students must be employable, must have the correct skill sets and knowledge, and as a result courses must meet the needs of industry and commerce (Cooper, 2002; 2006). It therefore goes without saying that employer engagement is vital, and improvements have been made in recent years. While differences in educational systems can be 
expected in many HEIs in Zimbabwe pertaining to tertiary qualifications needs and challenges in key sectors and areas of study, including but not limited to such fields as education, law, social sciences, medicine, mines, journalism, business studies, engineering, library and information sciences, economics and schools of architecture, employer engagement remains a key aspect in the production of a relevant graduate.

Tourism is recognised as an industry of the future that will drive the development of developing economies and marginalised communities of such economies. The Southern Africa Development Community (SADC) recognises the importance of tourism in the region as a foreign currency earner and above all a tool for alleviating poverty in marginalised communities However, tourism is a service industry, and central to the provision of quality service are well trained and highly motivated employees who can deliver a high level of value and good relations with each customer (Cooper and Shepherd, 1997; McIntosh, 1992). HEIs have always played a leading role worldwide in the training and development of human resources. Unlike other academic disciplines, tourism as a degree or diploma qualification offering only took off in the early 1980s (Cooper and Westlake, 1989; McIntosh, 1992). This therefore means that the curriculum content remains fluid.

\section{TourismEducation in Zimbabwe}

The development of hospitality training in Zimbabwe started well before independence with the establishment of the School of Hospitality and Tourism in Bulawayo, Zimbabwe's second largest city. This was later followed by the then Chinhoyi Technical Teachers College (now Chinhoyi University of Technology) and the University of Zimbabwe introduced a Bachelor of Science Degree in Tourism and Hospitality Management in 1996. More institutions followed suit with the Midlands State University introducing it in 2000, Harare Polytechnic in 2006, Mutare Polytechnic in 2007, Joshua Mqabuko Polytechnic in 2007 and Kwekwe Polytechnic in 2008. While the programme in most Universities and Polytechnics is just 10 years old, it faces the same dilemma as many researchers such as Barrows and Hobson (1993) have noted in their research. Most of the subjects and courses that form part of the curriculum for the Tourism and Hospitality programmes currently on offer are not related to the hospitality industry. It must be noted that some of the courses are even out-dated and cannot provide a match to the demands from the sector (Dai and Chang, 1999).

Dai and Chang (1999) identified four problems that are inherent in vocational education curriculum development. In their research they noted that the problems include the idea that curricula are not consistent with integration among different levels of vocational education and training. In addition to this, another problem noted by the researchers was that students in vocational education and training are facing too much pressure due to too many courses in their study, besides that professional courses are inadequate. The third problem they highlighted in their study was that the contents of the courses were out of date and thus not appropriate for their industries and finally the evaluation and appraisal of students cannot reflect the students' learning effectiveness.

Competencies needed in the job performance are one of the crucial indicators of effectiveness in developing curricula in vocational education. Competency means an observable behaviour which indicates that one performs his job, role, responsibility, and duties effectively. Generally, it includes knowledge, skill, and effectiveness (Tian, 2001). The hospitality industry encompasses a wide range of professions, including those related to food service and lodging. It goes without saying that curricula developers need to understand the skills and competencies required of those employed in the industry to ensure they train and produce the best graduates for any position. Hospitality leaders have long demanded that students graduating from industry-specific higher education programmes possess appropriate management skills and competencies required to remain competitive (Chung -Herrera et al., 2003; Agrusa, Tanner and Coats, 2004). These underscore the critical role of the educational experience and the importance of continuous curriculum development in shaping the industry's future leaders (Dopson and Tas, 2004)

Since the 1990s, the increase in the number of institutes of technology, from either newly founded institutes, or the upgrading of outstanding junior colleges, vocational education in Zimbabwe has been transformed from middle vocational education to higher vocational education. At the beginning of the $21 \mathrm{st}$ century, vocational education in the world reached a summit and faced a new era of diversity, information, and technology (Cooper, 2002; Lin, 2001; Chuang, 2000). However, Huang (2000) indicates that from a farsighted point of view, the future on vocational education must satisfy the demands of industry and society. Thus, to address this situation, the curricula of vocational education should be adjusted and amended in a timely fashion (Chuang, 2000).

Dai and Chang (1999) mention that, citing from Kang (2001), curricula for vocational education have four characteristics: (1) the objectives of curricula are to prepare students to have the ability to participate in the job market and perform their duties efficiently; (2) the planning of curricula needs to take the number of students, contents, materials and facilities into consideration and match the demands of the job market; (3) for the implementation of curricula there is a need to connect with industries and make the best use of the social resources which will contribute to students' career development; and (4) the evaluation of curricula needs to 
review students' knowledge, skills, attitudes, and value in school and their performance in the job market once they have graduated.

\section{Competencies needed in the Hospitality Profession}

Generally speaking, students who graduate from the hospitality disciplines are prepared to be entry-level managers in the hospitality industry. However, today, it is more difficult to be a manager than ever. They are expected to conquer more and more difficult issues, for instance, internationalization and multi-nationalization, multiculturalism, cultural diversity, and more decision making (Lewis 1993). It also goes without saying that researchers such as, Cooper and Shepherd (1997) pointed out that the following competencies are needed for hospitality students:

- operational analysis;

- on-the-job training skills;

- management meeting;

- negotiating skills;

- management of the service encounter;

- approaches to social training;

- managing changes;

- managing innovation and creativity.

The content of tourism curricula has been the subject of intense debate, with no conclusions reached as yet (Cooper and Shepherd, 1997; Gunn, 1998). One school of thought is in favour of a traditional academic curriculum development driven by the interest and specialisations of academics and other concerned faculty (Cooper and Westlake, 1992). The other school of thought is premised on the belief that the development of tourism curricula should be a partnership between the tourism industry and academic institutions thus leading to a systems approach.

Gunn (1998) brought a new dimension to the debate by advancing the argument that curriculum development should not lose sight of the difference between education and training. Education refers to making graduates aware of the human environment and how to cope with this environment while training equips trainees with skills that they can apply immediately to work situations. Gunn (1998) argues that education was the preserve of universities while training was proffered by polytechnics and other technical colleges. With the rising competition in the job market, this distinction has become blurred so that both types of HEIs have become career oriented in their approach and emphasise both types of learning.

The first school of thought outlined in this paper argues that there should be core curricula that HEIs should follow as a model (Stuart, 2001; 2002). Airey and Johnson (1999) have observed that most United Kingdom universities offering tourism degrees have already been following the concept of a core curricula, outlined as follows by Copper and Shepherd, (1997:4)

- The meaning and nature of tourism, and its relationship with leisure and recreation

- The structure of the tourism industry, key sectors in the industry and their principal operating characteristics and linkages within the industry

- The dimensions of tourism - internally and domestically - and issues of measurement

- The significance and impact of tourism

- Marketing - tourism applications

- Planning and development - tourism applications

- Policy issues, management of tourism, finance and organisation

In addition to this, Cooper et al (1992) argue that students should go through work-related placement to equip themselves with practical skills that enable them to decide whether they fit into the industry. Other study areas that could be added to the core curricula are communication skills, entrepreneurship, information technology, hotel operations, product knowledge, and marketing (Robinson and Wiscombe, 2008), host community development and sustainability (McIntosh, 1992), and knowledge of the language spoken by major source markets (Cooper, 2002; 2006).

The study by Manwa (2009) in Zimbabwe showed that there was consensus among operators that HEIs in Zimbabwe were not producing the right calibre of graduates for the tourism industry and this has resulted in the shortages in the following key operational areas of the tourism industry:

$\circ$ Visionary managers, in general to chart the way forward for the industry

- Food and beverage managers

- Qualified cooks and chefs who are able to create unique Zimbabwean dishes

- Qualified skinners for hunting safaris

- Professionals to lead water adventure activities such as white-water rafting and bungee jumping 
- Qualified drivers with good knowledge of the product range who can double as tour guides

- Customer care and public relations professionals

- Conference and functions managers

- Qualified tour operators and experienced tour guides

- Entrepreneurship development opportunities (Manwa, 2009)

The literature reviewed for this paper showed a dearth of research on tourism curriculum content from aZimbabwean perspective.

\section{Discussion}

Most tertiary qualifications have the majority of modules inclined to their function and thereby affording scholars an opportunity to learn what industry and commerce expect out of them. It is totally the opposite with most Hospitality qualifications that have bias towards science, finance and accounting, and as a result, the system is producing raw Hoteliers, Receptionists, Reservationists, Housekeepers, Chefs and Bakers. A rough scan of the Hospitality qualifications that are offered locally revealed that most of them offered only between $30 \%$ and $40 \%$ content inclined to Hospitality and Tourism management.

The hotelier as a professional, in addition to general management skills, only requires the fundamentals of the majority of what becomes core in their studies - economics, finance and accounting. The majority of the courses must focus on Hospitality and Tourism management. The other disturbing observation was that the limitation of Hospitality-related modules is spread across the certificate to degree in tertiary institutions that are offering Hospitality qualifications.

\section{Implication of this Paper}

The observations noted in this paper maybe used as suggestions for realigning the tourism and hospitality curricula in Zimbabwe. Cooper and Shepherd (1997) noted that the key to long-term success for the hospitality managers comes from a balance of education, training and experience. Utilising the consensus of the hospitality industry and hospitality faculty regarding the courses and curricula content is important for establishing effective hospitality programmes that meet the needs and demands of the hospitality industry in Zimbabwe.

As an applied discipline, hospitality education must have a close and strong linkage with its industry so that graduates keep abreast with the current industry trends and needs. Since the hospitality industry is a service oriented industry, there is an immediate need for most of the hospitality programmes in Zimbabwe to put more weight on industry expectations and opinions. In the Zimbabwean tourism and hospitality industry, a stronger link between the education programmes and the industry is imperative. The weakness of hospitality education in the country is the absence of a strategic link between industry and the education sector.

The tourism industry has been on a growth path since the formation of the inclusive government in 2009 and the industry has been cited as a key sector for the revival of the economy (STERP, 2009; ZTA, 2011). The hospitality sector has been the key contributor to the gross domestic product of Zimbabwe over the years and currently employs over 300000 workers (ZTA, 2011). The provision of hospitality services is generally agreed to be labour intensive and thus requires highly skilled workers. There is a strong positive correlation between the provision of quality hospitality education and the development and success of the hospitality industry. However, there is a strong indication that the current hospitality qualifications in Zimbabwe need revisions that will lead to major adjustments and improvements in an attempt to meet the needs and requirements of the industry.

It could be assumed that the provision of hospitality qualifications in Zimbabwe does not fully meet the current needs of the industry. If future methodologies of curriculum development remain as they are now, the gap between the industry's needs in qualified human resources and the effectiveness of the education system will continue to be wide.It is important to define a clear nationally recognised educational and skills scheme in terms of the hospitality qualification, training and practice

The literature reviewed in this regard showed that there is a general acceptance among scholars and tourism industry professionals that changes have to occur in the provision of hospitality training. However, these changes are often recommended by industry and not necessarily accepted by academics.

\section{Conclusions and Recommendations}

There is a growing demand for professionally educated and trained staff in the hospitality sector in Zimbabwe. However, current literature reveals a significant disparity between hospitality qualifications and skills required by the industry despite a rapid growth in the provision of hospitality higher education in Zimbabwe. A major challenge is the curricula content which does not address the key competencies required for the hospitality profession. 
Hospitality training should not be isolated from real practice and those involved in the development of the curricula must work closely with industry to ensure a strong connection between theory and practice. This will go a long way in improving the likelihood of having skilled hospitality graduates who are aligned with the needs and expectations of the hospitality industry. More importantly, content courses and subjects that form hospitality qualifications must be predominantly industry-related.

\section{References}

[1]. Agrusa, J., Tanner, J., and Coats, W. (2004). Hospitality, Restaurant, and Tourism Management Degree Programs

[2]. Airey, D and Johnson, S. (1999), The Content of Degree Courses in the UK, Tourism Management, Vol. 20, p. 229-235. and the Issue of Student Preparedness. Journal of Hospitality and Tourism Education, 16(1), 56-63.

[3]. Barrows, C. W., and Hobson, J. S. P. (1993). A model for teaching service management in hospitality.International Journal of Contemporary Hospitality Management, 5(3), 32-36.

[4]. Chuang, C. P. (2000). The anticipation of vocational education in next century. Technological and Vocational Education Journal Bimonthly, 55, 68-69.

[5]. Chung-Herrera, B., Enz, C., and Lankau, M. (2003). Grooming Future Hospitality Leaders: A competencies model.

[6]. Cooper, C and Westlake, J (1989), Tourism Teaching into the 1990s, Tourism Management, Vol. 10, p. 69-73.

[7]. Cooper, C and Westlake, J. (1998), Stakeholders and Tourism Education: Curriculum Planning Using a Quality Management Framework, Industry and Higher Education, Vol. 12, p. 93-100.

[8]. Cooper, C, Scales. R, and Westlake, J. (1992), The Anatomy of Tourism and Hospitality Educators in the UK, Tourism Management, Vol. 13, p. 234-247.

[9]. Cooper, C. (2002), Curriculum Planning for Tourism Education: from Theory to Practice, Journal of Teaching in Travel and Tourism, Vol. 2, p. 19-39.

[10]. Cooper, C. (2006), Knowledge Management and Tourism, Annals of Tourism Research, Vol. 33, p. 47-64.

[11]. Cooper, C. and Shepherd, R. (1997), Tourism Education and the Tourism Industry: Implications for Tourism Education , Tourism Recreation Research, vol. 22, p. 35-48.

Cornell Hotel and Restaurant Administration Quarterly, 44(3), 17-25.

[12]. Dai, W. S., and Chang, S. H. (1999). The revolution of vocational education curriculum. Technological and Vocational Education Journal Bimonthly, 54, 9-13.

[13]. Dopson, L., andTas, R. (2004). A Practical Approach to Curriculum Development: A case study. Journal of Hospitality\& Tourism Education, 16(1), 39-46.

[14]. Gunn, C.A (1998). Issues in Tourism curricula. Journal of Travel Research, 36, 74 -77

[15]. Huang, C. J. (2000). The proclaiming of future in vocational education. Technological and Vocational Education Journal Bimonthly, 55, 57-60.

[16]. Kang, T. L. (2001). The Development of Leadership Behaviour Inventory for the Vocational Schools in Taiwan. Journal of Human Resource Management, 1(3),43-57

[17]. Lewis, R. C. (1993). Hospitality management education: Here today, going tomorrow? Hospitality Research Journal, 17(1), 273-283.

[18]. Manwa. H, (2009). Development of a Tourism Curriculum: Lessons for the SADC

[19]. McIntosh, R.W. (1992) Early Tourism Education in the U.S., Journal of Tourism Studies, 3(1), 2-7.

[20]. media.unwto.ordg./sites/all/files/images/inforgraphic1.jpg.Accessed 11/03/2013

[21]. Pritchard, A, Morgan N, and Ateljevic, I. (2007), Tourism and Embodiment: Critical Issues of Gender, Sexuality and the Body, Wallingford, CAB International.

[22]. Robinson, P. and Wiscombe, C. (2008). The challenges of Employer Engagement: A critical comparison of innovative course delivery. HLST Conference 2008, 6th November 2008, St Anne's College Oxford

[23]. Smith, G and Cooper, C. (2000), Competitive Approaches to Tourism and Hospitality Curriculum Design, Journal of Travel Research, vol. 39, p. 90-95.

[24]. STERP (2009). Ministry of Finance, Harare

[25]. Stuart, M. (2001) Degrees of Difference: Influences of the Development of Tourism as a Subject in UK Higher Education PhD Thesis. University of Kent.

[26]. Stuart, M. (2002) Critical Influences on Tourism as a Subject in UK Higher Education: Lecturer Perspectives. Journal of Hospitality, Leisure, Sport and Tourism Education 1(1), 5-18.

[27]. Tian, C. S. (2001). The analysis model of student's competency and criteria by job oriented.Technological and Vocational Education Journal Bimonthly, 63,16-20.

[28]. UNWTO (2012) International tourist arrivals grew by $4 \%$ in 2012 to 1.035 billionhttp://mkt.unwto.org/en/barometer. Accessed $\underline{25 / 03 / 2013}$

[29]. ZTA Statistics(2012). $\quad$ Trends $\quad$ and http://www.zimbabwetourism.net/directory/index.php/downloads/category/tourism-trends. Accessed 12/02/2013 